\title{
TRANSLATING CULTURES: \\ THE CREATION OF SIN IN THE PUBLIC SPACE \\ OF BATSWANA
}

\author{
Musa W Dube \\ Department of Theology and Religious Studies \\ University of Botswana \\ Department of Biblical and Ancient Studies
}

UNISA

\begin{abstract}
This article seeks to trace the fussy boundaries of religion and the public space in the modern colonial archive of southern Africa. It investigates how drawing such boundaries became a central strategy in translating indigenous cultures into sin and creating guilt in communities that did not observe the sacred and secular boundaries. The article uses the attestations of the $19^{\text {th }}$ century letters to Mahoko a Becwana, a London Missionary Society public paper, printed from Kuruman. While the Batswana worldview kneaded religion and all spheres of individual and collective public space, modern western colonial perspectives claimed otherwise. This paper analyses the letters for the intrusion of colonial religion into the public space of Batswana; the colonial agenda to translate key cultural beliefs and activities into the realm of evil and the various responses it initiated - thereby uncovering that perhaps the separation of religion from state has always been a mythological and ideological construction.
\end{abstract}

Key Words: Translation studies; Postcolonial; Culture; Public Theology; Religion and the State; Translation Theory; Botswana; Sin

When we attempted to convince them of their state as sinners, they would boldly affirm ... that there was not a sinner in the tribe (Robert Moffat 1842:254).

\section{Introduction: Colonial Border-crossing and New Boundaries}

A colonial context and its subsequent postcolonial settings generate multiple border-crossings and translations. In his Sociology of Colonies: An Introduction to the Study of Race Contact Vol 1, Rene Manuier thus says, "This is the conception of Empire: ... to know no bounds" (1949:19). Manuier cites the example of the Babylonian sovereign Hammurabi who gave himself the title of "King of the four corners of the world" (19). That is, the empire and its colonial project involves crossing multiple boundaries into other people's lands and drawing many new boundaries to claim the lands as its own, especially where there are competing colonial powers. We all know the agenda of the Berlin Conference of 1884, which sought to co-ordinate the process of crossing various boundaries into African lands and drew new boundaries for claiming what the colonisers had named for themselves as 'a big blank map' of Africa (Moffat 1842:2; Conrad 1902:4). And so there was a 'colony rush' to claim some pieces of the supposedly big blank map, and to draw boundaries of claim by various imperial powers. Today we bear upon our bodies this history of drawing and redrawing of colonial boundaries as we identify ourselves as English-speaking Africa, French-speaking Africa and Lusophone 
Africa. Most, if not all, contemporary national boundaries are products of modern colonial agenda. Of course there was no such thing as a big blank map, since the African continent was fully occupied by African people. The colonising powers needed to sanctify their conscience through constructing an ideology of 'a big blank map.' The ideology of a big blank map was painted in various hues such as racial, cultural, economic and religious superiority of the colonising powers. The modern colonial project therefore involved multiple border-crossing into other people's lands and social spheres as well as drawing new boundaries on top of various existing boundaries.

As Manuier's subtitle, "An Introduction to the Study of Race Contact" highlights, the colonial border-crossing is all about contacts of various races - for the map is never blank. Any colonial border-crossing thus generates a contact-zone (Pratt 1992:6-7). Mary Louise-Pratt defines the contact-zone as, "the space of colonial encounters, the space in which people geographically and historically separate come into contact with each other to establish ongoing relations" (6-7). It follows that the colonial multiple border crossing is, as always, more than just physical border-crossing. It always includes the cultural, political, economic, social, sexual and religious border-crossing, for all lands are also bearers of cultural constructions of their inhabitants and visitors. Border-crossing is a power-laden activity which involves the identities of those who cross and their reasons. Hence in my article, Batswakwa: What Kind of Traveller are you? I have argued that various travellers must identify their power and the reasons behind their border-crossing (2000:89-99). In this postcolonial era, the theory of border-crossing is championed by former colonised subjects as they find their way to the imperial centres (Azandula 1999 \& Bhabha 1994). Just as Salmon Rushdie coined the famous phrase, "the Empire writes back" (Ashcroft, Griffiths \& Tiffin 1989) we could say in the contemporary era, "the Empire travels back," to the metropolitan centres many times as powerless, but insistent travellers, who will not be deterred by various border patrollers (Guardiola-Saenz 1997:69-81). They enter imperial centres as undocumented workers, students, migrants, politically and economically displaced persons or highly trained professionals, searching for greener pastures (Brah 2003:613-634). Today border-crossing is intensely theorised, as the former colonised subjects return to imperial centres to claim back what was taken from them by their colonial masters (Spencer-Miller 2004:209-238); to share in the commonwealth. Border-crossing, as theorised by the former colonised, is a framework that challenges the established western-based paradigms and insists on looking beyond the established boundaries to other historical, cultural or canonical realities (Said 1992:317).

\section{Translation as Creative Rewriting}

As bearers of self-proclaimed superior social structures, modern colonial travellers claimed for themselves the right to redraw all boundaries of the colonised - psychically, economically, politically, socially, culturally and religiously. Clearly border-crossing is a power-laden game within which both the travellers and the hosts find themselves entangled. Both the traveller and the host come to a new boundary, if not multiple boundaries, where new languages of being and survival are needed. Translation thus becomes a central part of border-crossing because one's own language(s) becomes insufficient to communicate with the various border-crossing communities. According to Edwin Gentzler, "traditional definitions of translations invariably include a border over, or through which translation is carried across" (2012:1) normally between two sources: the source text and target culture. The source text is often regarded as the original which should be preserved while the target text or culture is supposedly the passive recipient of the latter. A translation, in such frameworks of understanding must be faithful to 
http://scriptura.journals.ac.za

the original text. This understanding of translation is far from being ideologically neutral, for the target cultures are supposedly instrumental and passive recipients of the culture of the original source, while the original source is to be preserved at all costs. In short, the original source crosses over and sub-plants itself in the target-culture. The targeted culture supposedly makes room for the new original source. In the colonial context, it was the colonial language, culture, religion, political and economic systems that became the original text. As Bassnett and Trivedi highlight, in the colonial context "Europe was regarded as the great Original, the starting point, and the colonies were therefore copies, or 'translations' of Europe, which they were supposed to duplicate. Moreover, being copies, translations were evaluated as less than originals" (1999:4).

This dualistic framework, which is still held by many translation theorists and practitioners, has been critiqued from multiple angles for its ideological trappings and shortcomings. From a feminist standpoint, this is a gendered perspective, which views translation as an act of the male depositing his seed in the womb of a female body, which is thought of as nothing but a recipient and carrier of the planted seed. Contemporary translation studies have complicated this picture of translation. It is recognised that "the borders transgressed in translation tend to be more multiple and permeable than traditionally conceived" (Gentzler 2012:1). Originals are already translations of translations. Moreover, the so-called originals translate themselves at the borderlands to new identities. Hence many prisoners, outlaws, prostitutes and low class peasants in colonial contexts played the imperial race card and assumed a new cocoon of superiority in the colonies (Strobel 1991:1-16). Similarly target cultures are far from being passive recipients of the seeds of so called original sources. They too translate themselves whenever the situation demands. If a target culture can be viewed as a woman's womb receiving the seed of the original source, the woman's womb will feed the baby from its own supply for nine months, give it her genes and give birth to a child who is not a duplicate of the father but a product of both. If we imagine that the baby is also externally nurtured by the mother feeding it from her own breast then far from being a duplicate of the original source, a translation is always a hybrid product - a new product. Target cultures, far from being passive recipients who must remain faithful to the so-called originals, are also active potters who reshape the colonial mud in their hands. So every translation is a creative rewriting of both the original and receiving cultures. It is a new product.

\section{The Imposed Categories of the Secular and the Sacred}

It follows that the colonial contact-zone of the Batswana and the Europeans was a huge translational project, one that turned cultures at the contact zone inside out and upside down, multiple times and continuously. It was characterised by continuous multiple border-crossings, from both races, especially where religious beliefs were concerned. First, concerning religion, it is important to highlight that in so far as Batswana or Bantu people of Southern Africa were concerned, there was no division between the secular and the sacred. If such a division existed, it was not marked in dualistic forms. The worldview of Batswana and Bantu people in general was marked by interconnections of the dead and the living, of culture and religion, of people and the environment. The Batswana (and most Bantu people of Southern Africa) did not have a theological concept that regarded all human beings as inherently sinful and in need of repentance and saving. Rather, the Batswana and most Bantu people had a concept of acceptable relational living, which was measured by one's relationship to family, community, the environment and the Divine powers (Ancestors and God). This relational perspective is best captured by the popular saying, "motho ke motho ka batho," in Sotho-Tswana or "umuntu ngu 
muntu nga bantu" in Nguni languages. The saying holds that a human being is only human through other human beings. One's goodness and humanity were measured by the capacity to relate to others. What could pass as 'sinful' would be the disruption of these relationships, which necessitated rituals of reconciliation.

Accordingly, one did not have to make a choice to become a believer, since one was never outside belief as long as one was living according to the communal norms. Similarly there was no division between the public and private spheres of religion or separation of religion and state. Faith was kneaded together with community beliefs and practices of daily living, such that drawing lines of division between religion and civic matters in the public and individual context creates imposed categories. The duty of a Kgosi, as the leader or King of Morafe, or the people, was often also that of a religious leader, who surrounded himself with religious leaders, dingaka (Moffat 1842:208; Schapera 1948:60-69). Faith was manifested as public, political and economic practice in the rituals that consisted of the well-being of Morafe. As noted by Isaac Schapera in his book, A Handbook of Tswana Law and Customs, this included performing rituals for rainfall in times of drought or at the beginning of the rainy season, doctoring mephato, the army, in preparation of war and in the installation of a new Kgosi (1948:70).

The arrival and introduction of Christianity would thus encounter new boundaries of belief and practice as well as attempt to draw new ones upon the Setswana culture. Since a major Christian assumption is that all humanity has sinned and fallen short of God's glory, the first major challenge confronting early missionaries was that the idea of an inherently sinful human being did not exist among the Batswana. The salvation of Jesus Christ was thus rendered unnecessary and irrelevant. So Robert Moffat writes that "when we attempted to convince them of their state as sinners, they would boldly affirm with full belief in their innate rectitude that there was not a sinner in the tribe" (1842:254).

Robert Moffatt records that he was sometimes laughed at, told that his preaching was maaka hela (just lies), asked if he did not tire of speaking about this certain Jesus, while at other times, he was empathetically advised to cease his teaching, for he risked been taken for mad. Likening preaching to Batswana as the art of trying to break water from a granite rock, Moffatt lamented: "Oh when shall the day-star arise in their hearts? We preach, we converse, we catechise, we pray, but without the least apparent success..." (285). The process of rewriting or translating Batswana's self-understanding, for them to understand themselves as inherently sinful and in need of the salvation became crucial for the Christian gospel to sell (Dube 2013:88).

Clearly, before the concept of an inherently sinful individual could be cultivated, it was important to construct a sinful community. My research regarding the colonial Bible translation into Setswana showed that colonial translation rewrote Badimo (ancestors) as demons to convince Batswana that they were evil and in need of Christian salvation (1999:33-59). So in the Setswana New Testament translation, Jesus went around casting Badimo out. The translation was one of the most powerful ways of creating sin among Batswana, for by the time the first Batswana read the Setswana Bible translation they discovered that that which they held sacred was in the realm of evil in the biblical text.

How did the cultural translation occur and how did the Batswana respond to it? How does such a translation reflect Christian religion in the public space? To explore these questions, I will largely read the letters that the Batswana sent to the editor of Mahoko a Becwana, a newspaper that was published by the London Missionary Society (henceforth LMS) from Kuruman, between 1883-1896. A number of 'literate' Batswana wrote letters on various 
subjects, which gives us a window into how Batswana responded to translation of Setswana culture and how it reflects religion in the public space. The editors occasionally published letters concerning correct Christian practice, which often stimulated long discussions. These letters were recently collected and made available in the volume Words of Batswana: Letters to Mahoko a Becwana 1883-1896, edited by Part T Mgadla and Stephen C Volz. I wish to examine the case of: Bogadi (bridewealth) and Magosi and Thuto (rulers and the biblical/Christian teaching) closely as well as highlight some debates on wedding dances (mmero le setapa), initiation schools (Bogwera le Bojale) and crop medicine. I must underline that in reading these letters, written between 1883 and 1896, we are quite a distance from Robert Moffat's days, where he was ridiculed and ignored for his Christian teachings. The fact that these Batswana wrote letters to the editor speaks for itself. It means that they had undergone the missionary teaching and school and most probably were Christians, although even the unconverted had learnt how to write and read from those who went to school. Politically, Botswana was now officially a British Protectorate. These letters attest to the centrality of religion in the public space of Botswana (then Bechuanaland) and are important for highlighting what was finally defined as sin and how it was accepted and contested by others. The various letters that are analysed and cited in this article are found in the Mgadla and Volz compilation of 2006.

\section{Bogadi: Bridewealth}

The section opens with a letter from Alfred Wookey, the editor, dated October 1883. He writes:

The teaching (Bible//Christian teaching) has encountered the Tswana law called bogadi, bride wealth...It was written by one person, and he said to me, "If a person has taken bogadi what is wrong with that?"... God simply gave Adam a woman in the beginning and also gave him children; there is no bogadi at all other than thanking God for his gifts. Today also, God has appointed the man for the woman and the woman for the man not by payment. If God pleases, he gives them children, they are not bought. Psalm 127:3 says children are inheritance of Jehovah: I say why do believers want to return to the deeds of the darkness such as these? This practice of bogadi was an activity that was done by the people of long time ago who did not know anything about God... This is shameful. God has not commanded such a thing... We have been bought by the blood of the son of God, who is Jesus. And things of the darkness should be thrown away, along with each and every one of their remnants (Mgadla \& Volz 2006:139).

Editor Wookey uses the biblical text to dismiss bogadi. He argues that the creation story (Genesis 1-2) does not feature bogadi and the Psalms state that children are a blessing from God. Categorising bogadi as 'a shameful' act, which is among "deeds of the darkness," Wookey argues that it "should be thrown away." Of course, Wookey's selective reading of Genesis notably overlooks that patriarchs, such as Isaac and Jacob, had to offer some bridewealth for their wives Rebekah, Leah and Rachel. Jacob had to offer fourteen years of service to his uncle, Laban, for his two wives. Wookey's letter was followed by fifteen letters, the dates of which range from 1883 to 1890 . Some writers agreed with the editor, naming bogadi as a 'bad and evil' practice of buying women or children (141-142) which apparently persists among believers and non-believers alike. As Morolong Monnaakanye asserts, "there isn't any believer who is not involved in this evil deed of Bogadi ... because the believer will take bogadi and the one who does not believe will take bogadi" (142). Apparently the bogadi had been discussed over a long time and still the resolution could not be reached. Part of the complication was that in the Setswana legal system, bogadi constituted a confirmation of a marriage, without which the relationship did not qualify as a marriage among Batswana. 
Bogadi was the proof of marriage, the legal seal. Consequently, the people who choose not to receive or give bogadi entered a marriage that was not legally recognised and it created multiple complications to participants and their children in the event of death or divorce.

Respondents who wrote in defence of the practice gave several reasons. First, they argued that bogadi is not buying children or a wife, rather it is a confirmation of marriage, just as in the Western manner, marriage is confirmed through a church or magistrate wedding, where a couple exchanged rings (2006:157). Second, since cows are central to Botswana culture, they feature in all important occasions, including marriage. Third, bogadi is an expression of gratitude to the parents and relatives who raised the bride. Fourth, the translation of bogadi in commercial terms is strongly rejected as a Western imposition. Against such claims that bogadi is 'buying' a woman or children, Baruni Makutle writing in May 1884 argues, "I don't know how bogadi changed into buying...You know that the practice of Batswana is not to buy a person. If one of them comes from a journey, and he has gone to buy a person, he will be shunned. It will be said, 'It is a bad omen, we will perish.' We discovered the buying of a person through the Europeans, and that is how we saw that a person can be bought" (147). Underlining that bogadi is not about buying children or women, and contesting the slavery language, Joseph Molokwane writes in January 1891:

Regarding bogadi, we Batswana do not say that it is buying. We understand very well that a person cannot be bought by anything in this world. But you say that bogadi is buying. Go and get some cattle, even more than hundred, and buy the child of some man with them. Even if her father is embarrassingly poor, I don't believe that you can see such a person anywhere... how can a person be sold, since she has a soul in the image of God? (157).

Notably he also employs the creation story of Genesis 1, just as Wookey did, but for a different interpretation of bogadi. This section closes with a letter from Kgosi Montshiwa, who underlines the centrality of bogadi. He writes, "Bogadi is not wrong; it should be paid. Of all Tswana things, it is the one that establishes marriage" (161).

Turning to the case of magosi le thuto (rulers and the biblical/Christian teaching), the letter of editor Alfred Wookey opens the debate. Its contents, as we shall see below, highlight the centrality of religion in the public space of Batswana of colonial times, while it also demonstrates how indigenous cultures and worldviews were re-written as evil, but not without strong resistance from Batswana writers of the time.

\section{Dikgosi le Thuto: Translating Government}

... the issue of rulers and (Christian) teaching. Rulers have been saying, "the teaching destroys; it is destroying villages and people." Dikgosi have feared the teaching for a long time and fought against it. So today, some dikgosi regard teaching simply as a snake that should be killed. However, Christian teaching has remained firm and has been difficult to kill. Many people have believed, and there are many congregations and school buildings. There are many people who know the books. Rulers are divided; some have believed and others do not believe. And perhaps among the rulers who don't believe, there are many people who believe, and a missionary and Christian teaching are regarded by dikgosi only as an enemy.

Because it has been difficult to kill Christian teaching and remove it, now dikgosi have changed and are saying that the teaching should be regulated. A teacher should be supervised in a way that he teaches and in a way that he works. It is said that a congregation should only be governed by dikgosi... It is said that when a church is built, it should be built by dikgosi conscripting people to work. Even those who do not believe should pay and do manual 
http://scriptura.journals.ac.za

Translating Cultures: The Creation of Sin in the Public Space of Batswana

labour. It is said that the house of God should be that of dikgosi and that they should order it to be opened or closed and for teaching or no teaching to take place inside. It is said that dikgosi should be told the secrets of the congregation, and that no one should be cut off for an offence and no one admitted without the agreement of the rulers...in some villages we see that the one who is the elder of the village is also the elder of the congregation. Even those who are believers are divided... [But] when a person tries to mix ruling the village with managing the congregation, that is how he destroys it. ... You know the congregation is for God; it is not for the missionary, it is not for anyone, it is for God. Christian teaching came to earth as a different thing, not from dikgosi. Faith is a feeling in a person's heart that cannot be restrained and controlled by anyone.... We will not be stubborn, but we plead with dikgosi to leave us alone and allow us to pray to God, congregate, advise one another, teach people and build churches as we like. Dikgosi allow us to pay taxes and have us do tasks that are appropriate for you to order. But don't try to intervene in that which is of God, our faith...What we are sure of is this: chieftainship will not control anything in the house of God. It cannot control things of the congregation. No one should say that a congregation is his. A congregation belongs to God, and churches belong to the congregations that have built them (237-239. See also 247-249).

This letter, quoted at length, was written in November 1889 by Wookey when he was serving as the editor of the newspaper (xxiii). John Brown, who assumed the editorship in 1891, also returned to the same issue in a letter written in 1892 entitled, 'evil leaven' (247). Wookey's letter is crucial for it highlights the multiple border crossings and redrawing of the social boundaries that occurred with the introduction of Christianity into the public space of the Batswana. It is also crucial in the sense that it highlights how the Batswana social fabric was translated and how they translated themselves several times to deal with the new phenomenon. First, we note that the major agent of change is named as thuto, or biblical/Christian teaching. The introduction of thuto, and what he calls books, namely the Bible, has drawn a new major boundary in the public space of Batswana: dividing the community into two categories of those who believe and those who do not believe the teaching, thuto. In a society that did not separate the sacred and the secular and where public leaders also held some priestly roles, or worked hand in glove with the indigenous religious leaders (dingaka), this division had a major impact on the public space of Batswana communities, as the letter itself attests.

Since dikgosi were initially unifying figures and the Setswana cultures were communal, Christian teaching had planted a major division, which questioned and weakened the power of dikgosi and Setswana culture. As Wookey states: "the law that governs a congregation is in the scriptures of God" (239). There were now some sections of the society, which were supposedly outside the jurisdiction of dikgosi and Setswana culture and were under another authority. Major aspects of the Setswana culture had been translated to the realm of evil. The thuto brought with it books and resulted in believers, congregations, the missionaries, God, church and school buildings, which were defined as outside the powers of dikgosi, the rulers of the people. With the introduction of the thuto, believers could now solve their own disputes without involving the Kgosi.

These new believers-non-believers boundaries were received with tension, resistance and/or outright rejection. As the letter attests, dikgosi named the thuto, or Christian teaching, an enemy and a snake and accordingly tried to kill it. They had fully grasped its poison. The thuto, however, continued to thrive, forcing the dikgosi to revise their strategy to translate themselves from being opponents of the thuto to become its patrons. They sponsored the church and school buildings and reasserted their authority by insisting that Christian institutions and structures remain under the authority of dikgosi, and by continuing to adjudicate cases of disputes 
between believers who had been tried in the church. Clearly, the public space had become a contested space due to the introduction of thuto, Christian teaching. The writer is clear that dikgosi have overstepped their boundaries by attempting to extend their leadership powers to the believers and their institutions. There is now a place in the society where dikgosi's powers had no mandate. Thus he insists, "faith is a feeling in a person's heart that cannot be restrained and controlled by anyone ..." (239) thereby employing the private or individual space versus the public space to distance dikgosi's power over believers. Wookey goes on to give an imperative: "don't intervene in that which is of God ... chieftainship will not have anything in the house of God" (239). This letter seems to suggest the separation of religion from the state, particularly where the writer says: "Dikgosi, allow us to pay taxes and have us do tasks that are appropriate for you to order. But don't try to intervene in that which is of God, our faith... What we are sure of is this: chieftainship will not control anything in the house of God" (329). Writing in the post Bechuanaland Protectorate of 1885, Wookey notably exudes great authority in his speech towards dikgosi.

The editor's letter was followed by a flurry of letters (about twelve), taking various positions: some confirming that dikgosi interference is indeed undesirable; others highlighting that believing dikgosi continue to hold on traditional roles (See Molefi Mogapi 1893). Other writers, however, contested Wookey's attempt to separate the church from the state. One such letter was written by Molema Moshwela, who adopts a non-contentious tone while appreciating how different dikgosi have supported the work of the church by hosting travelling evangelists, building churches and schools (242-243). In so doing he underlines that he does not regard the involvement of dikgosi in thuto as inherently problematic, nor does he regard dikgosi as enemies of thuto - Christian teaching. Others contested Wookey's letter by underlining that missionaries and evangelists' adjudication of disputes between believers is often unfair and leads to unfair expulsion of people from the churches (243 \& 247). Other writers wrote back in defence of their dikgosi, who had been named as unworthy believers, for they still carry out rainfall rituals (249-254). In his letter of June 1893, Mhiko Segadika adopted the Setswana perspective of Kgosi ke kgosi ka batho, (all decisions of a Kgosi are only through his people and by his people) to insist that dikgosi do not act on their own - rather they fulfill the demands of their people, morafe (249-253). In so doing, Segadika underlines that dikgosi (their decision and acts) cannot be separated from the people. Others sought to underline that dikgosi can and have furthered the gospel and used bogosi (leadership) to further Christian goals, hence linking faith and bogosi does not always disadvantage the goals of Christian teaching. One such letter was written by Rratshosa M Segokotlo in April 1896 about Sir Khama Sekgoma and his government. He asserts:

I am trying to record the accomplishment of the government of Sir Khama Sekgoma, the way he is ruling us as his nation. Khama has ended all the practices of his forefathers. Our forefathers used to say, rain is made to fall by the rainmaker and kgosi. A woman was married with cattle, a person could be killed without any thought, people were forced to be initiated, alcohol was drunk... when it did not rain, like this year, it was said that it was being withheld by a person, and some person and his wife would be taken and put in the sun. There were also charms, sacrifices and many taboos about things of the world. When Sekgoma ruled, these things were being done but he sought the teaching of the word of God for his children. Khama, Khamane, Seretse and Kebailele all studied. In 1872 when Khama came to power, he told his morafe, "I am informing you that I am stopping childish things," meaning those things that I have listed (Mgadla and Volz. 259). 
http://scriptura.journals.ac.za

Translating Cultures: The Creation of Sin in the Public Space of Batswana

Notably there was no letter from the missionaries contesting Khama's use of bogosi to further the missionaries' biblical/Christian teaching! Religion thus remains in the public space before and after the thuto, or Christian teaching.

\section{To Dance or not to Dance and Other Cultural Translations}

Sebotseng Leoabile writes in April 1884, "I am asking about a song called mmero or setapa, and I say, isn't this song a useless song? How is it that I see it being danced by the believers? I say it is a useless song like the ones that I was dancing when I was still a heathen, but now I have left them because they are useless songs that do not honour God" (217). The editor missionary responds, "Sebotseng is right to ask about the song. It seems it is sometimes a source of evil, sometimes missionaries reject it" (217). The editor explains that one group of believers came to seek permission to dance to it, and they were permitted to dance a little. However, they danced so much that "they were found to be exhausted from all the dancing so that the young women and men nearly fainted. How can missionaries relax the laws if people continue to be wild when the law is relaxed just a little?" (217). Endorsing this perspective, Yob Mosieleng wrote in July 1884 that "we saw young women and men (believers) who were dancing a song called Setapa... We explained to them that the setapa was sinful. Even though they did not listen to us..." (217). Resistance was plenty even amongst the believers. This particular group of dancers had been confronted by other believers who sent them off to go and think things over; namely, "to repent or not to repent" (219) concerning their participation in the wedding dance. After reflection, they said "they did not see how they could stop setapa" (219).

Such contestations over day to day indigenous cultural practices were daily bread. Writing in September 1890, Bananni Diphafe states: "the way I know crop medicine, it is a great heathenism" (199). Michael Tshabadira Moroka writes back: "I want to understand correctly. Are you saying that crop medicine is sinful or heathenism? Or is it against the laws of God or of Europeans?" (203). It is clear that believers and the general public were quite aware that some restrictions had very little to do with biblical teaching, but much to do with selling Western civilisation as the norm. So several writers express doubt concerning the foundation of the prohibitions. Indeed Brown's comment on the wedding dance is quite telling, when he names it as 'wild.' Believers are prohibited to participate in the wedding dance lest they overstep the boundaries of Western civilisation and appear to be wild. But judging from the response of the above-mentioned group of dancers, many believers were resisting believers.

Concerning the initiation schools, Gaabuiwe Masige in his July 1891 letter begins the debate, which was followed by a very long letter from the editor John Brown dated September 1981. Brown tabulates the tensions between parents and sons and between dikgosi and missionaries concerning participation in initiation schools. While earlier on editor Brown had characterised the involvement of rulers in church matters as the 'evil leaven,' he concludes his long letter by hoping for the intervention of the colonial government: "We heard from the magistrate that the government has agreed to consider the laws regarding boys' and girls' initiation; they want to see how they might be changed. Even the Administrator's secretary has written us so. We hope that a law that helps believers to protect their children from evil ways will in the meantime be enacted" (229) (emphasis mine). The writer does not provide us with information on whether missionaries had submitted a proposal to the colonial governing power regarding initiation schools. But it is strongly implied, since it seems the colonial government had taken advice from someone; namely "the government has agreed." It is also implied that the colonial government regarded them as partners in the project, for both the magistrate and 
the Administrator's secretary kept them informed as interested parties. Brown's letter highlights religion in the public space and the definition of sin as the rewriting of indigenous cultures into the realm of evil. But as always there were voices of protest. Mosimanyane, for example, writes, "I know you are not God. You can prohibit your own children from attending boys' and girls' initiation, but leave me alone. Mine will be going. I do not want Christian faith. It is lies that it promotes. Europeans have long been deceiving us" (129).

\section{Conclusion}

In the above-mentioned debates and counter arguments, it is apparent that sin was defined according to practices that were found unacceptable to Western missionaries. Such activities could have religious connotations or could be plain cultural activities - if such a demarcation exists at all. Examples are evident in questions concerning such issues as biblical teaching (thuto), wedding dances, (setapa or mmero), initiation schools (bogwera and bojale) and crop medicine raised in Letters to Mahoko a Becwana. The outline of these various debates highlights that when sin was finally defined, it was the customs and norms and practices of Batswana that were translated into sin. These were now labelled as darkness, great heathenism, sinful, useless, source of evil, evil ways and, according to Alfred Wookey, "things of the darkness, which should be thrown away" (139). Since these were accepted communal practices, naming them as evil painted the whole community as sinful. As my investigation into the Setswana Bible translation has shown, the crucial desire to convict Batswana as sinful and in need of Christian salvation, included translating the word demons, with Badimo, that is, ancestors (1999:33-59).

The translation was one of the most powerful ways of creating inherent sin among Batswana, for when the first Batswana readers read the Holy Book in their own language, they discovered that that which they held sacred supposedly belonged in the realm of evil in the Bible. This translation of general norms of Batswana into evil was in fact not just the creation of guilt in individuals; it was also the translation of the public space through Christian religion. Gone were the days that Batswana could tell Moffatt that there was not a single sinner in their midst! In Christian teaching, as in the indigenous worldview, religion was central to the public space - which became an arena of power struggles in the modern colonial context. But such a colonial translation never went unnamed, uncontested or disconnected from colonial strategies by Batswana writers. As underlined by Mosimanyane's above-mentioned assertion, ("I do not want Christian faith. It is lies that it promotes. Europeans have long been deceiving us"), there was resistance, collaboration and outright rejection.

\section{BIBLIOGRAPHY}

Anzandula, G 1999. Borderlands/La Frontera: The New Mestiza. Aunte Lute Books: San Francisco.

Ashcroft, B, G Griffiths \& H Tiffin 1989. The Empire Writes Back: Theory and Practice in Postcolonial Literatures. New York: Routledge.

Bhabha, H 1994. The Location of Culture. Routledge: New York.

Bassnett, S \& Trivedi H (eds.) 1999. Postcolonial Translation: Theory and Practice.

New York: Routledge. 
Brah, A 2003. "Diaspora, Border and Transnational Identities," in: Reina Lewis and Sara Mills (eds.), Feminist Postcolonial Theory: A Reader. Routledge: New York 2003:613-634. here, 613.

Conrad, J 1902. Heart of Darkness. New York: Bantam Books.

Dube, MW 2013. "The Bible in the Bush: The First 'Literate' Batswana Bible Readers," in: Translation: Issue 2:79-104.

Dube, MW 2000. “Batswakwa: Which Traveller Are You (John 1:1-18)?” Journal for Theology for Southern Africa. 108:79-89.

1999. "Consuming a Colonial Cultural Bomb: Translating Badimo into 'Demons' in the Setswana Bible," in: Journal of Society of New Testament 73:33-59.

Gentzler, E 2001. Contemporary Translation Theories ( $2^{\text {nd }}$ edit.). Clevedon: Multilingual Matters.

Guardiola-Saenz, L 1997. "Borderless Women and Borderless Texts: A Cultural Reading of Matthew 15:21-28," in: Semeia 78 1997:69-81, here 71-72.

Louise-Pratt, M 1992. Imperial Eyes: Travel Writing and Transculturation. New York: Routledge.

Maunier, R 1949. The Sociology of Colonies: An Introduction to the Study of Race Contact. Vol 1. London: Routledge.

Mgadla, P \& Volz SC (translators/compilers) 2006. Words of Batswana: Letters to Mahoko a Becwana 1883-1896. Cape Town: Van Riesbeck Society.

Moffat, R 1842. Missionary Labours and Scenes in Southern Africa. London: J Snow.

Said, E 1993. Culture and Imperialism. Alfred Knopf: New York.

Schapera, L 1938. A Handbook of Tswana Law and Custom. London: Frank Cass.

Spencer-Miller, A 2004. "Lucy Bailey meets the Feminists," in: Kathleen O'Brien Wicker,

Althea Spencer Miller and Musa Dube (eds.), Feminist New Testament Studies:

Global and Future Perspectives. New York: Palgrave, 209-238.

Strobel, M 1991. European Women and the Second British Empire. Bloomington:

University Press. 